\title{
MOLECULAR GENOTYPING OF TSST-1 GENE STAPHYLOCOCCUS AUREUS FROM CLINICAL SPECIMEN
}

\author{
Marinda Dwi Puspitarini' ${ }^{1}$, Wahyu Setyarini ${ }^{2}$, Usman Hadi ${ }^{3}$, Kuntaman Kuntaman ${ }^{3}$ \\ ${ }^{1}$ Basic Medicine Postgraduate Program, Faculty of Medicine, Universitas Airlangga \\ ${ }^{2}$ Institute of Tropical Disease, Universitas Airlangga \\ ${ }^{3}$ Department of Microbiology, Faculty of Medicine, Universitas Airlangga/Dr. Soetomo General Academic \\ Hospital, Surabaya, Indonesia
}

\begin{abstract}
Staphylococcus aureus (S. aureus) is the most common pathogen in humans that causes various infections. Variations in infections due to $S$. aureus are related to the presence of virulence factors, one of which is Toxic Shock Syndrome Toxin-1 (TSST-1) which is the main cause of Toxic Shock Syndrome (TSS). This study aimed to explore the genetic pattern of the tsst-1 genes among MSSA and MRSA from clinical isolates of patients at Dr. Soetomo General Academic Hospital, SurabayaIndonesia. PCR examination was performed on 106 clinical samples of S. aureus isolates to determine the presence of the tsst-1 genes; subsequently, phylogenetic analysis was performed. The positive tsst-1 genes were found in 3 (5.7\%) MSSA isolates and $2(3.8 \%)$ MRSA isolates from 106 samples, of which were divided into 53 MSSA isolates and 53 MRSA isolates. No significant difference was noticed between the tsst-1 genes on both the MSSA and MRSA bacteria $(p=0.648)$. The positive tsst-1 genes were found in 1 (4.5\%) of pus specimens and 2 (16.7\%) of blood specimens from MSSA isolates. However, the positive tsst-1 genes were found in neither sputum nor urine specimens. The genes were found in 2 (16.7\%) of blood specimens from MRSA isolates. Based on the phylogenetic tree, Indonesian tsst-1 isolates belonged to the same clade as Japan, Iran, Iraq, India, Egypt and the United Kingdom isolates. The prevalence of tsst-1 genes of both MSSA and MRSA from clinical isolates in Dr. Soetomo General Academic Hospital Surabaya are 5.7\% and 3.8\%, respectively. The tsst-1 genes of Surabaya-Indonesia, Japan, Iran, Iraq, India, Egypt and the United Kingdom belonged to the same clade.
\end{abstract}

Keywords: MSSA; MRSA; toxic shock syndrome toxin-1; phylogenetic

\section{ABSTRAK}

Staphylococcus aureus (S. aureus) merupakan patogen paling sering pada manusia yang menyebabkan berbagai macam infeksi. Variasi infeksi akibat $S$. aureus dihubungkan dengan adanya faktor virulensi salah satunya yaitu Toxic Shock Syndrome Toxin-1 (TSST-1) yang merupakan penyebab utama Toxic Shock Syndrome (TSS). Penelitian ini bertujuan untuk mengeksplorasi pola genetik gen tsst-1 antara MSSA dan MRSA dari isolat klinis pasien di rumah sakit Dr. Soetomo, Surabaya-Indonesia. Dari 106 sampel isolat klinis staphylococcus aureus dilakukan pemeriksaan PCR untuk mengetahui adanya gen tsst-1 dan selanjutnya dilakukan analisis phylogenetic. Dari 106 sampel terbagi menjadi 53 isolat MSSA dan 53 isolat MRSA didapatkan gen tsst-1 positif sebanyak 3 (5,7\%) isolat MSSA dan 2 (3,8\%) isolat MRSA. Tidak didapatkan perbedaan yang bermakna antara gen tsst-1 dengan bakteri MSSA dan MRSA. Distribusi gen tsst-1 positif pada spesimen pus sebanyak 1 (4,5\%) dari isolat MSSA dan spesimen darah 2 (10,5\%) isolat akan tetapi tidak ditemukan pada spesimen sputum maupun urin sedangkan pada isolat MRSA hanya ditemukan pada spesimen darah sebanyak 2 (16,7\%) isolat. Isolat tsst-1 dari Indonesia dalam satu clade dengan Negara Jepang, Iran, Irak, India, Mesir dan Inggris mengacu pada hasil phylogenetic tree. Prevalensi gen tsst-1 pada (MSSA) dari isolat klinis di RSUD Dr. Soetomo Surabaya sebesar 5,7\% sedangkan MRSA sebesar 3,8\%. Berdasarkan hasil phylogenetic tree didapatkan gen TSST-1 dari Surabaya dalam satu clade dengan negara Jepang, Iran, India, Irak, Inggris dan Mesir.

Kata kunci: MSSA; MRSA; toxic shock syndrome toxin-1; phylogenetic

Correspondence: Kuntaman, Department of Microbiology, Faculty of Medicine, Universitas Airlangga, Surabaya, Indonesia/Dr. Soetomo General Academic Hospital, Surabaya, Indonesia. Email: kuntaman@fk.unair.ac.id

pISSN:2355-8393 • eISSN: 2599-056x • doi: 10.20473/fmi.v57i2.17559

- Fol Med Indones. 2021;57:129-134 • Received 24 Jan 2020 • Accepted 09 Apr 2020

- Open access under CC-BY-NC-SA license • Available at https://e-journal.unair.ac.id/FMI/ 


\section{INTRODUCTION}

Staphylococcus aureus (S. aureus) is the most common pathogen found in humans that causes a wide variety of infections ranging from superficial skin and soft tissue infections to death-causing infections such as endocarditis, osteoarticular infections, pneumonia and bacteraemia. The therapeutic choice at the beginning of the development of $S$. aureus infection was the penicillin class of antibiotics. After some reported cases of penicillin resistance, new antibiotics such as methicillin was developed (Boswihi \& Udo 2018). Methicillin is a semi-synthetic antibiotic of the $\beta$-lactam group, which kill bacteria by inhibiting bacterial cell wall synthesis. Short after usage of methicillin, it emerged methicillin resistant Staphylococcus aureus (MRSA), that resistance against all beta lactam antibiotics. MRSA resistance was identified encoded by mecA gene that expressing the PBP $2 b$ that has no affinity against beta lactam antibiotic, and induce the beta lactam resistance (McGuiness et al 2017).

Variations in $S$. aureus infection are associated with virulence factors, such as adhesion and exo-protein factors which consist of exotoxins and enzymes, including nuclease, protease, lipase, hyaluronidase, and collagenase. Exotoxins produced by $S$. aureus are $\alpha$ haemolysin, $\beta$-haemolysin, $\gamma$-haemolysin, PantonValentine leukocidin (PVL), Toxic Shock Syndrome Toxin-1 (TSST-1), Staphylococcal Enterotoxins (SE) and Exfoliative Toxins (EF) (Bien et al 2011, Motamedifar et al 2015, Oliveira et al 2018). Toxic Shock Syndrome Toxin (TSST-1) is an example of the SAgs exotoxin group that has the ability of pyrogenicity, super-antigenicity and crossing the surface mucosa. The tsst-1 encoding genes are present in the pathogenicity islands produced in the post-responsive phase. Toxic Shock Syndrome Toxin (TSST-1) is a small, non-glycosylated, polypeptide molecule weighing around $22 \mathrm{kD}$. The toxin is stable to chemicals, resistant to hot and dry conditions (Dinges et al 2000).

Toxic Shock Syndrome Toxin-1 (TSST-1) is one of the main virulence factors and the main cause of Toxic Shock Syndrome (TSS) (Teyhoo et al 2014). Toxic Shock Syndrome Toxin-1 (TSST-1) has the ability to activate $\mathrm{T}$ lymphocytes through a direct bond between the $\mathrm{T}$ Cell Receptor (TCR) V $\beta$ with the Major Histocompatibility Complex class II (MHC II) molecules. The activation results on the production of pro-inflammatory cytokines, including Interleukin (IL2), Interferon (IFN) and Tumor Necrosis Factor (TNF) causing symptoms of high fever, reddish rash, desquamation, hypotension, and acute, life-threatening multi organ failure of which are the symptoms of TSS
(Bien et al 2011, Motamedifar et al 2015, Oliveira et al 2018). The ability of bacteria to cause infection depends on the number of virulence factors from bacterial colonisation. The characteristics of virulence factors of each MSSA and MRSA may vary related to the length of treatment and the possibility of mortality (Motamedifar et al 2015). Research on MSSA and MRSA bacteria producing TSST-1 toxin from clinical isolates of patients in Indonesia is still rarely found.

This study aimed to explore the genetic pattern of the tsst-1 genes among MSSA and MRSA from clinical isolates of patients at Dr. Soetomo General Academic Hospital, Surabaya-Indonesia.

\section{MATERIALS AND METHODS}

\section{Bacterial Isolates}

All bacterial isolated, namely Methicillin sensitive Staphylococcus aureus (MSSA) and Methicillin resistant Staphylococcus aureus (MRSA) were collected from clinical isolates of hospitalized patients in Dr. Soetomo General Academic Hospital Surabaya. The bacterial were cultured and identification according to the routine procedure in this hospital. After sub-culture in primary medium, the growth colonies were to identify and AST by BD Phoenix ${ }^{\mathrm{TM}}$ Automated Microbiology System or Vitek2 system, that had been carried out at the Clinical Microbiology Laboratory of Dr. Soetomo General Academic Hospital, Surabaya. All isolates were stored at deep freeze in $-80{ }^{\circ} \mathrm{C}$.

\section{DNA Isolation and PCR Amplification of the tsst-1 Genes}

DNA extraction was carried out using the TE boiling method. MSSA and MRSA samples were cultured on Manitol Salt Agar (MSA) media and incubated at $37^{\circ} \mathrm{C}$ for 24 hours. The colony was then inoculated with a sterile transfer loop in an Eppendorf Tube containing $100 \mu \mathrm{L}$ TE buffer. The suspension was then dissolved using a vortex and heated at thermostat (Eppendorf, North America) temperature of $95^{\circ} \mathrm{C}$ for 10 minutes, respectively. Following the heating, the tube was cooled to room temperature and was centrifuged at $10,000 \mathrm{rpm}$ for 10 minutes. The extracted DNA was stored at $-20^{\circ} \mathrm{C}$ before amplification (Kuntaman et al 2016). PCR amplification procedure was run in $25 \mathrm{ul}$ mixture, consisting of $3.5 \mu \mathrm{L}$ DNA template, $12.5 \mu \mathrm{L}$ PCR mix (DreamTaq Green, Thermo Scientific, USA), $0.5 \mu \mathrm{L}(50 \mathrm{pmol})$ for each of the primers for gene tsst-1 and $8 \mu \mathrm{L}$ of distilled water to make a $25 \mu \mathrm{L}$ mixture of PCR reaction. Forward primers: 5'-ACC CCT GTT 
CCC TTA TCA TC-3 'and reverse primers: 5'-TTT TCA GTA TTT GTA ACG CC-3' were used to make an amplicon product of $326 \mathrm{bp}$ (Mehrotra et al 2000). DNA was amplified using a thermal cycler PCR (Icycler, Biorad Thermal Cycler). An initial denaturation step was run at $95^{\circ} \mathrm{C}$ for 6 minutes and followed by a separate 32 cycles of denaturation at $95^{\circ} \mathrm{C}$ for 1 minute, annealing at $55^{\circ} \mathrm{C}$ for 35 seconds, and extension at $72^{\circ} \mathrm{C}$ for 30 minutes, and the cycles was ended by $72^{\circ} \mathrm{C}$ for 10 minutes respectively (Alni et al 2018). The reaction products were run in $1.5 \%$ agarose gel electrophoresis with ethidium bromide staining. DNA bands were then visualised and observed using a UV transilluminator (Spectroline, Spectronic, USA).

The amplicon of tsst- 1 gene was sequenced using Applied Bio system ABI 31308 capillary sequencer as manufacture procedure. The result of sequence analyzed with CLC Sequence Viewer version 7.6 software, nucleotide and protein used Lasergene Megalign 7.0 software and build phylogenetic tree with MEGA X.

\section{Statistical Analysis}

The difference in the proportion of the tsst-1 genes between MSSA and MRSA bacteria was analysed using the SPSS Mann-Whitney test. The $\mathrm{p}$ value of $<0.05$ indicated a significant difference.

\section{RESULTS}

\section{Bacterial Isolates}

A total of 106 isolates were collected during the study since July until October. The bacterial isolates were consisting of 53 MSSA bacterial isolates and 53 MRSA bacterial isolates. Out of 53 MSSA bacterial isolates, $22(41.5 \%), 19(35.8 \%), 10(18.9 \%)$ and $2(3.8 \%)$ isolates were taken from pus, blood, sputum and urine specimens respectively. Meanwhile, out of 53 MRSA bacterial isolates, $24(45.3 \%), 17(32.1 \%), 12(22.6 \%)$ isolates were taken from pus, blood and sputum specimens respectively. The 53 MSSA bacterial isolates were collected from $32(60.4 \%)$ males and $21(39.6 \%)$ females, whereas 53 MRSA came from 29 (54.7\%) male and $24(45.3 \%)$ females respectively. The patients ranged from baby below one year of age up to 80 years old, that mostly at 51-60 years old show in Table 1 .
Table 1. The characteristics of specimens, genders and age groups of MSSA and MRSA isolates

\begin{tabular}{|c|c|c|}
\hline & \multicolumn{2}{|c|}{ Bacterial Number } \\
\hline & MSSA (\%) & MRSA (\%) \\
\hline \multicolumn{3}{|l|}{ Specimens } \\
\hline Pus & $22(41.5)$ & $24(45.3)$ \\
\hline Blood & $19(35.8)$ & $17(32.1)$ \\
\hline Sputum & $10(18.9)$ & $12(22.6)$ \\
\hline Urine & $2(3.8)$ & $0(0.0)$ \\
\hline Total & $53(100)$ & $53(100)$ \\
\hline \multicolumn{3}{|l|}{ Genders } \\
\hline Male & $32(60.4)$ & $29(54.7)$ \\
\hline Female & $21(39.6)$ & $24(45.3)$ \\
\hline Total & $53(100)$ & $53(100)$ \\
\hline \multicolumn{3}{|l|}{ Age groups } \\
\hline $0-10$ years & $11(20.8)$ & $11(20.8)$ \\
\hline $11-20$ years & $11(20.8)$ & $5(9.4)$ \\
\hline $21-30$ years & $1(1.9)$ & $5(9.4)$ \\
\hline $31-40$ years & $5(9.4)$ & $6(11.3)$ \\
\hline $41-50$ years & $7(13.2)$ & $3(5.7)$ \\
\hline $51-60$ years & $10(18.9)$ & $18(33.9)$ \\
\hline $61-70$ years & $4(7.5)$ & $4(7.5)$ \\
\hline $71-80$ years & $4(7.5)$ & $1(1.9)$ \\
\hline Total & $53(100)$ & $53(100)$ \\
\hline
\end{tabular}

MSSA: methicillin-sensitive Staphylococcus aureus; MRSA: methicillin-resistant Staphylococcus aureus

\section{The tsst-1 Genes in Clinical Isolates}

The tsst- 1 genes were identified using the PCR method. The results of electrophoresis of tsst- 1 genes are displayed in Figure 1. The positive tsst-1 genes were found in $5(4.7 \%)$ isolates of 106 isolates, consisting of $3(5.7 \%)$ MSSA isolates and $2(3.8 \%)$ MRSA isolates. No significant difference was found between the tsst-1 genes on MSSA and MRSA bacteria $(p=0.648)$. Table 2 showed characteristic of the positive tsst- 1 genes on MSSA and MRSA isolates based on specimens, genders and age groups. The positive tsst- 1 genes on MSSA isolates, were found in $1(4.5 \%)$ and $2(10.5 \%)$ isolates, from pus and blood specimens, respectively. However, the positive tsst-1 genes were not found from both of sputum and urine specimens. The positive tsst- 1 genes on MRSA isolates were only found in $2(16.7 \%)$ isolates from blood specimens. The spread of tsst- 1 distribution among specimens, sex and age show in Table 2.

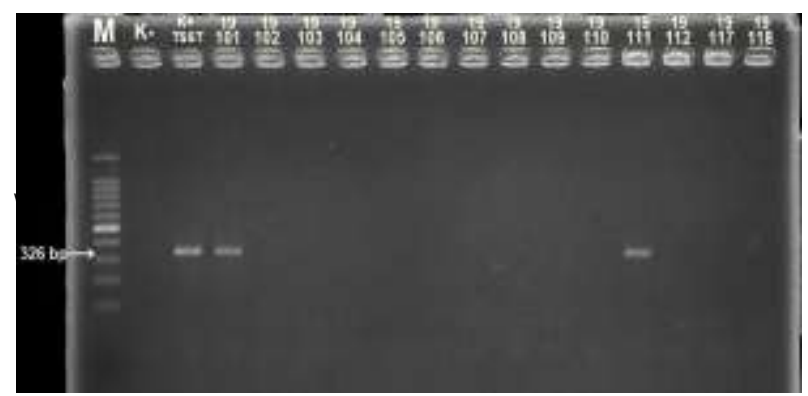


Figure 1. Electrophoresis of the tsst-1 genes from MSSA and MRSA bacteria.

Note: M: Marker 100bp DNA ladder, K-: negative control, $\mathrm{K}+$ : positive control of Staphylococcus aureus N315, 101-118: sample codes. 326bp: positive band of DNA of tsst-1 genes

Table 2. Characteristic of the positive tsst-1 genes on MSSA and MRSA isolates based on specimens, genders and age groups

\begin{tabular}{lll}
\hline & $\begin{array}{l}\text { MSSA (\%) } \\
\text { Positive tsst-1 genes }\end{array}$ & $\begin{array}{l}\text { MRSA (\%) } \\
\text { Positive tsst-1 genes }\end{array}$ \\
\hline Specimens & & \\
Wound & $1(4.5 \%)$ & 0 \\
Blood & $2(10.5 \%)$ & 0 \\
Sputum & 0 & $2(16.7 \%)$ \\
Urine & 0 & 0 \\
\hline Genders & $1(3.1 \%)$ & $1(3.4 \%)$ \\
Male & $2(9.5 \%)$ & $1(3.4 \%)$ \\
Female & \\
\hline Age groups & & 0 \\
0-10 years & $1(9.1 \%)$ & \\
\hline
\end{tabular}

\begin{tabular}{lll}
\hline $11-20$ years & $1(9.1 \%)$ & $1(20 \%)$ \\
$21-30$ years & 0 & 0 \\
$31-40$ years & 0 & 0 \\
$41-50$ years & 0 & 0 \\
$51-60$ years & 0 & $1(5.6 \%)$ \\
$61-70$ years & $1(9.1 \%)$ & 0 \\
$71-80$ years & 0 & 0 \\
\hline
\end{tabular}

MSSA: methicillin-sensitive Staphylococcus aureus; MRSA: methicillin-resistant Staphylococcus aureus; tsst-1: toxic shock syndrome toxin-1

\section{DNA Sequencing and Phylogenetic Analysis of the tsst-1 Genes}

The sequence of tsst-1 genes, one of the examples in Figure 4 analysis of the nucleotide sequences and amino acid sequences of the tsst- 1 genes was run using the Tamura-Nei neighbour-joining method.

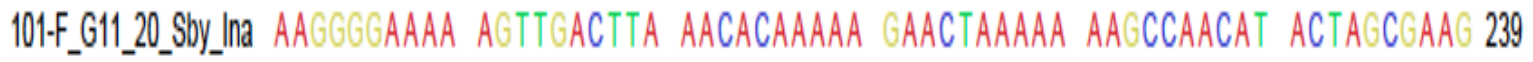

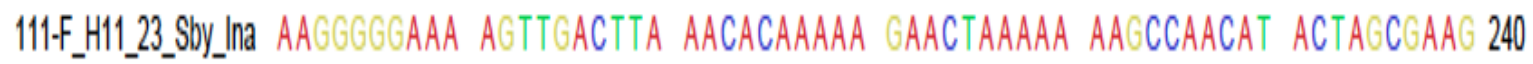

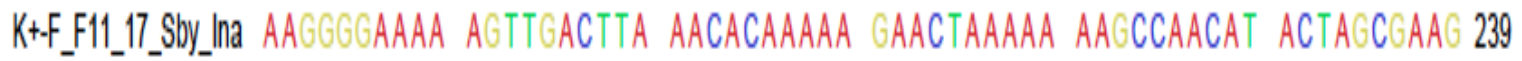

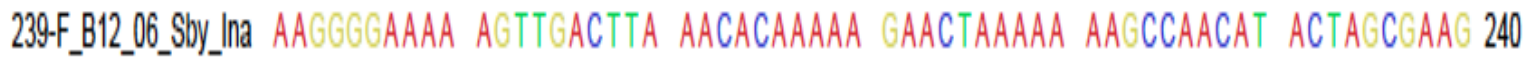

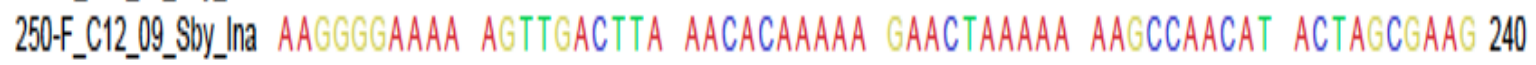

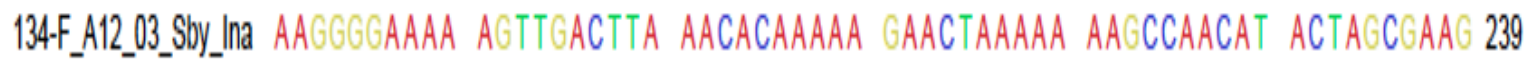

Figure 4. Sequence of tsst-1 genes sample

The phylogenetic tree of the isolates obtained in the current study and isolated from other countries, using the Tamura-Nei method showed in Figure 5. Two clades were found. The first clade consisted of animals from Egypt and Switzerland, and consisted of food from Egypt. The second clade consisted of clinical isolates of MSSA and MRSA bacteria from Surabaya-Indonesia, Japan, United Kingdom, Iran, Egypt, Iraq and India; animals from Thailand and India; as well as animal products from Egypt. Although MSSA isolate samples with code 111-F belonged to the same clade as samples from Japan, they still had a genetic variation of $0.35 \%$. Other MSSA isolate samples with code 101-F had similar genetic variation to MSSA isolate samples with code 134-F. The MSSA isolate samples with codes 134$\mathrm{F}$ and $239-\mathrm{F}$ have a genetic variation of $0.35 \%$. Two MRSA isolate samples with codes $239-\mathrm{F}$ and $250-\mathrm{F}$ had the same genetic variation as the 2 latter samples.

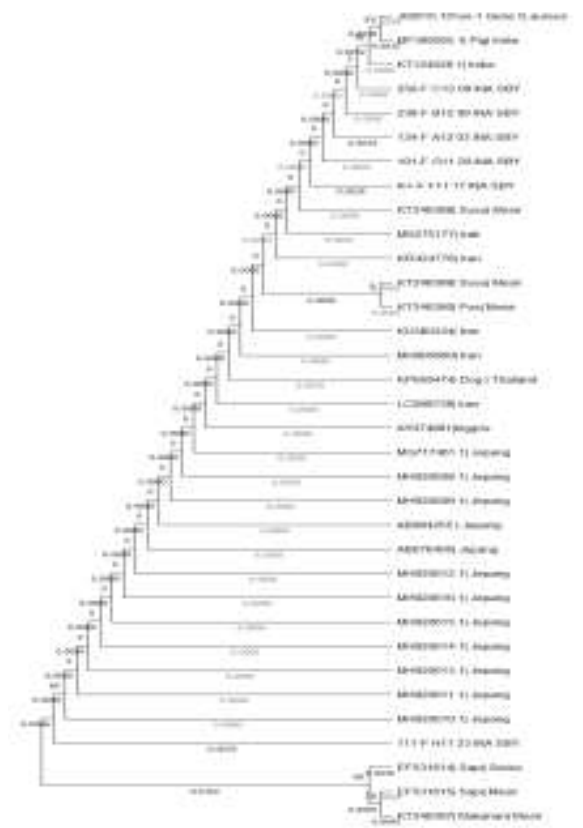


Figure 5. Phylogenetic tree of positive tsst-1 samples. Notes: 101-F, 111-F, 134-F, 239-F and 250-F: bacterial isolates of MSSA INA-SBY

\section{DISCUSSION}

Staphylococcus aureus is one of the important pathogenic bacteria that causes infection in humans, in both of the hospital and the community environment (Teyhoo et al 2014). Infections due to S. aureus caused a long hospital stay, antibiotic use, high cost and mortality (Alni et al 2018). The ability of the bacteria in causing infection was supported by the presence of virulence factors, one of which was Toxic Shock Syndrome Toxin (TSST-1) which can cause Toxic Shock Syndrome (TSS) (Teyhoo et al 2014).

The prevalence of tsst- 1 gene in MSSA and MRSA were low, $3(5.7 \%)$ in MSSA and $2(3.8 \%)$ in MRSA respectively, and there was no significantly difference between MSSA and MRSA. The results were similar to a study conducted in Malaysia in 2013; of which found that the proportion of tsst- 1 genes in MSSA strains was $13.3 \%$ greater than the proportion of the genes in MRSA strains. However, the Malaysia study found no MRSA bacterial strains that had tsst-1 genes. In 2011, $6.8 \%$ positive tsst- 1 genes of 518 MSSA strains were reported (Sapri et al 2013). As any as 7.5\%, 5\% and $23 \%$ positive tsst-1 genes were also reported from Lybia (El-Ghodban et al 2016), Lebanon (Tokajian et al 2011) and Iran (Sabouni et al 2014) respectively. In 2015, positive tsst-1 genes were discovered in $14.3 \%$ MRSA and $19.3 \%$ MRSA isolates in an Iran study with the total sample of 345 Staphylococcus Aureus (Motamedifar et al 2015).

In a study performed in Thailand, was not identified of tsst-1 genes neither in 36 isolates MSSA nor 56 isolates MRSA bacterial strains (Indrawattana et al 2013). Recent report in 2014 from two Iran hospital, found positive tsst- 1 genes in 2 MSSA isolates and 18 MRSA isolates from 100 isolates Staphylococcus Aureus and another hospital found 12 MRSA isolates positive tsst-1 genes in from 84 isolates Staphylococcus Aureus (Teyhoo et al 2014). In 2015, another Iranian study discovered positive tsst- 1 genes in 56\% MSSA isolates and $69.8 \%$ MRSA isolates (Koosha et al 2015). Besides, in 2018, the positive tsst- 1 genes were mostly noticed in the MRSA bacterial strain except for one isolate derived from the MSSA bacterial strain (Alni et al 2018).

A study carried out in Japan displayed a larger proportion of the tsst- 1 genes that was $75 \%$ of 152 samples of MRSA bacterial strain isolates (Nagao et al
2009). The difference between virulence factors in MSSA and MRSA bacteria was still debatable of which depended not only on genotype, but also on geographical distribution.

Wound is a type of specimen that is the main source of the production of the tsst-1 genes from Staphylococcus Aureus (Teyhoo et al 2014). The current study found 3 specimens with positive tsst- 1 genes, including isolates from the specimens of wound, blood and sputum. Similar results were also obtained in Iran and Austria. Both studies in two latter countries discovered the positive tsst- 1 genes were mostly derived from blood and wound (Eftekhar et al 2017, Roetzer et al 2016). The different results were obtained in Nigeria and Malaysia that the tsst-1 genes were not found in wound samples, but were found in samples of both vaginal fluid and respiratory (Ezeamagu et al 2017, Lim et al 2012). The tsst- 1 genes could be found from diverse specimens of different substances of the patient's body. The present study described that the presence of positive tsst-1 genes was not comparable with the incidence of TSS; hence, the tsst-1 gene expression was influenced by various regulatory factors.

The tsst-1 isolates from Indonesia were categorised in the same clade as tsst-1 isolates from Japan, Iran, Iraq, India, Egypt and United Kingdom. The Indonesian specimens were also found to be similar to animals and animal product specimens from India, Thailand and Egypt. Nevertheless, isolates from Indonesia differed in clade from specimens found in animals and food originated from Egypt and Switzerland. The results of the present study displayed a diversity that was characterized by changes in the composition of proteins that affected differences in the expression of the tsst-1 genes. The findings still required further research on mutagenesis.

\section{CONCLUSION}

The prevalence of tsst-1 genes of both MSSA and MRSA from clinical isolates in Dr. Soetomo General Academic Hospital Surabaya were 5.7\% and 3.8\% respectively. Based on tsst-1 gene sequencing showed that the MSSA isolates with code 111-F need further mutagenesis analysis, because there were changes of amino acid. The phylogenetic tree, tsst-1 genes from Surabaya-Indonesia was categorised as the same clade with tsst-1 genes from Japan, Iran, India, Iraq, Egypt and United Kingdom. 


\section{REFERENCES}

Alni RH, Mohammadzadeh AP, Mahmoodi, et al (2018). Detection of toxic shock syndrome toxin (TSST) gene among staphylococcus aureus isolated from patients and healthy carriers. Avicenna J Clin Microb Infec 5, 1-5.

Bien J, Sokolova O, Bozko P (2011). Characterization of virulence factors of Staphylococcus aureus: novel function of known virulence factors that are implicated in activation of airway epithelial proinflammatory response. Journal of Pathogens 2011, $1-13$.

Boswihi SS, Udo EE (2018). Methicillin-resistant Staphylococcus aureus: An update on the epidemiology, treatment options and infection control. Current Medicine Research and Practice 8, 18-24.

Dinges MM, Orwin PM, Schlievert PM (2000). Exotoxins of staphylococcus aureus. Clinical Microbiology Reviews 13, 16-34.

Eftekhar F, Rezaee R, Azad M, et al (2017). Distribution of adhesion and toxin genes in Staphylococcus aureus strains recovered from hospitalized patients admitted to the ICU. Arch Pediatr Infect Dis 5, 1-8.

El-Ghodban A, Ghenghesh KS, Ma'rialigeti K, et al (2006). PCR detection of toxic shock syndrome toxin of Staphylococcus aureus from Tripoli, Libya. Journal of Medical Microbiology 55, 179-182

Ezeamagu C, Imanatue I, Dosunmu M, et al (2017). Detection of methicillin resistant and toxin-associated genes in Staphylococcus aureus. Beni-Suef University Journal of Basic and Applied Sciences 7, 92-97.

Indrawattana $\mathrm{N}$, Sungkhachat $\mathrm{O}$, Sookrung $\mathrm{N}$, et al (2013). Staphylococcus aureus clinical isolates: Antibiotic susceptibility, molecular characteristics, and ability to form biofilm. BioMed Research International 13, 1-11.

Koosha RZ, Hosseini HM, Aghdam EM, et al (2016). Distribution of TSST-1 and mecA genes in Staphylococcus Aureus isolated from clinical specimens. Jundishapur J Microbiol 9, 1-8.

Kuntaman, Hadi U, Setiawan F, et al (2016). Prevalence of methicillin resistant staphylococcus aureus from nose and throat of patients on admission to medical wards of Dr. Soetomo Academic Hospital, Surabaya, Indonesia. Southeast Asian J Trop Med Public Health 47, 66-70.

Lim K, Lee G, Park M, et al (2010). Genetic relationship between sccmec types and virulence factors of methicillin-resistant Staphylococcus aureus clinical isolates in Korea. J. Exp. Biomed. Sci 16, 7582.

Mcguinness WA, Malachowa N, Deleo FR (2017). Vancomycin resistance in staphylococcus aureus. Yale Journal of Biology and Medicine 90, 269-281.

Mehrotra M, Wang G, Johnson WM (2000). Multiplex pcr for detection of genes for staphylococcus aureus enterotoxins, exfoliative toxins, toxic shock syndrome toxin 1, and methicillin resistance. Journal of Clinical Microbiology 38, 1032-1035.

Motamedifar M, Ebrahim-Saraie HS, Alfatemi SMH, et al (2015). Frequency of the toxic shock syndrome toxin-1 gene in methicillin-susceptible and -resistant Staphylococcus Aureus isolates from teaching hospitals in Shiraz, Iran. Revista da Sociedade Brasileira de Medicina Tropical 48, 90-93.

Nagao M, Okamoto A, Yamada K, et al (2009). Variations in amount of TSST-1 produced by clinical methicillin resistant staphylococcus aureus (MRSA) isolates and allelic variation in accessory gene regulator (agr) locus. BMC Microbiolog 9, 1471-2180.

Oliveira D, Borges A, Simões M (2018). Staphylococcus aureus toxins and their molecular activity in infectious diseases. Toxins 10, 1-19.

Roetzer A, Haller G, Beyerly J, et al (2016). Genotypic and phenotypic analysis of clinical isolates of Staphylococcus aureus revealed production patterns and hemolytic potentials unlinked to gene profiles and source. BMC Microbiology 16, 1-14.

Sabouni F, Mahmoudi S, Bahador A, et al (2014). Virulence factors of Staphylococcus aureus isolates in an Iranian Referral Children's Hospital. Osong Public Health Res Perspect 5, 96-100.

Sapri HF, Sani NAM, Noordin A, et al (2013). Epidemiological study on Staphylococcus aureus isolates reveals inverse relationship between antibiotic resistance and virulence repertoire. Indian J Microbiol 53, 321-322.

Teyhoo M, Mobaiyen H, Amirmozafari N, et al (2014). Prevalence of toxic shock syndrome toxin I producing clinical isolates of Staphylococcus aureus strains isolated from hospitals in Tabriz, Iran. International Journal of Biosciences 4, 169-176.

Tokajian S, Haddad D, Andraos R, et al (2011). Toxins and antibiotic resistance in staphylococcus aureus isolated from a major hospital in Lebanon. ISRN Microbiology 2011, 1-9. 